\title{
DINAMIKA BUDAYA PEWAYANGAN KE ARAH DUNIA REALITA DALAM WAYANG PESISIRAN
}

\author{
Endang Nurhayati, Mulyana, Siti Mulyani, Hardiyanto, dan Doni Dwi Hartanto \\ Universitas Negeri Yogyakarta \\ email: endang_nurhayati@uny.ac.id
}

\begin{abstract}
(Title: The Dynamics of Puppet Culture Towards The World of Reality in Wayang Pesisiran). The world of puppetry is so attached to Javanese society where the changes of the times does not detract from the existence of puppets in Javanese people's lives. This study aims to describe the characteristics of coastal puppets and the dynamics of puppet culture towards the world of reality in coastal puppets using qualitative approaches. The data source used is a video of coastal puppets and interviews to Ki Kartono. Data is collected by means of listen, record, and interview. The data analysis used was the qualitative analysis of Miles \&Huberman (1992). Based on the results of research, coastal puppet shows always begin by introducing the mission of the show and introducing the main characters in the play to be told. The cultural dynamics of puppetry towards the world of reality in coastal puppets contain at least six dynamics, namely: a) religious; b) greetings; c) the territory of the country; d) socio-cultural; e) the growth of life (kasampurnaning dumadi); and f) employment. The dynamics that occur in the world of puppetry indicates the dynamic in Javanese puppetry in an effort to continue to maintain its existence in modern times today.
\end{abstract}

Keywords: cultural dynamics, the world of reality, wayang pesisiran

\section{PENDAHULUAN}

Setiap bangsa memiliki ciri khas kebudayaan yang menjadi pembeda antara satu bangsa dengan bangsa lainnya. Kebudayaan merupakan keseluruhan sistem gagasan, perasaan, tindakan, dan karya yang dihasilkan oleh manusia dalam kehidupan masyarakat yang menjadi miliknya dengan cara belajar (Koentjaraningrat, 2003, p.72). Secara sederhana, kebudayan dapat dikatakan seluruh aktivitas manusia dalam suatu masyarakat yang dilaksanakan guna memenuhi kebutuhan hidupnya. Kebudayaan memiliki sifat-sifat yang tidak bisa terlepaskan satu dan yang lainnya. Sifat-sifat kebudayaan antara lain; a) kebudayaan itu beraneka macam; b) kebudayaan dapat diteruskan secara sosial dengan pengajaran; c) kebudayaan dapat dijelaskan dalam komponen-komponen biologi, sosiologi, dan psikologi; d) kebudayaan memiliki struktur; e) kebudayaan mempunyai nilai; f) kebudayaan itu dinamis; serta g) kebudayaan dapat dikelompokkan dalam banyak bidang/aspek (Widyosiswoyo, 1992). Seluruh sifat-sifat kebudayaan tersebut melekat erat dalam sebuah hasil budaya dan masyarakat pemiliknya.

Terdapat banyak sekali kebudayaan yang diwariskan secara turun-menurun dari satu generasi ke generasi selanjutnya, salah satunya ialah wayang. Wayang merupakan merupakan prototipe kesenian tradisional yang begitu merakyat dari budaya Jawa (Basir, 2009, p.43). 
Wayang menjadi salah satu warisan budaya yang masih bertahan dan eksis dalam perkembangan zaman yang serba global. Wayang telah diterima sebagai warisan budaya yang bernilai adiluhung. Hal tersebut telah diakui secara internasional bahwa wayang menjadi warisan dunia oleh Organisasi Pendidikan, Keilmuan, dan Kebudayaan PPB (UNESCO) pada tanggal 7 November 2003. Oleh UNESCO, wayang ditetapkan dalam daftar Masterpiece of Oral and Intangible Heritage of Humanity. Tanggal tersebut kemudian diperingatan sebagai Hari Wayang Nasional oleh Pemerintah Indonesia (www.timesindonesia.co.id). Hal tersebut menjadi bukti bahwa wayang memiliki nilai yang begitu adiluhung dan diakui tidak hanya di masyarakat Jawa tetapi secara global.

Keberadaan sebuah kebudayaan yang adiluhung dianggap sebagai sebuah given (berian) yang diwariskan secara turun-temurun dan selayaknya dihayati dan diterapkan dalam kehidupan sehari-hari (Rahyono, 2009, pp.1314). Artinya, sebuah budaya yang bernilai adiluhung sudah selayaknya terus dijaga dan dilaksanakan dalam kehidupan sehari-hari, terlebih budaya-budaya tersebut memuat nilai-nilai yang mampu dimanfaatkan dalam keseharian masyarakat penerusnya. Eksistensi pewayangan Jawa dikarenakan adanya faktor dimana wayang tidak hanya digunakan sebagai media hiburan saja, akan tetapi menjadi sebuah gagasan kebudayaan yang mampu menjadi sarana pembelajaran bagi dan pendukung kebudayaan masyarakat. Pembelajaran yang dimaksud meliputi aspek-aspek seperti pendidikan, sosial, budaya, politik, maupun ekonomi (Normina, 2017, p.18). Latar belakang tersebutlah yang menjadi tonggak utama eksistensi wayang dalam masyarakat Jawa khususnya. Nilai-nilai tersebut secara nyata masuk ke dalam kehidupan masyarakat dan dilaksanakan sehari-hari.
Aspek-aspek pembelajaran dalam pewayangan tersebut merupakan salah satu dari dua hal pokok dari pagelaran wayang secara konvensional. Pagelaran wayang memiliki fungsi sebagai tontonan dan tuntunan. Pagelaran wayang tidak terbatas pada tontonan budaya saja, tetapi juga sebagai tuntunan dalam kehidupan, di mana nilai-nilai dari cerita pewayangan dapat diinternalisasikan dalam kehidupan (Ma'ruf, Komariah, \& Wildan, 2020, p.755). Pada umumnya ketika seseorang melihat wayang, perhatian utama bukan pada wayangnya, tetapi pada lakon atau bayangan dirinya yang seolah-oleh masuk dalam ceritanya. Dengan menonton wayang, seseorang dapat mengintrospeksi perilaku dan sifat pada tokoh pewayangan yang mirip dengan karakternya (Nurhayati, 2008, pp.138-139). Tontonan dan tuntunan dalam dunia pewayangan selalu mengikuti arus perkembangan zaman. Inilah yang membuat wayang mampu eksis hingga saat ini. Hal tersebut mengindikasikan bahwa wayang sebagai hasil dari sebuah kebudayaan memiliki dinamika yang secara dinamis mampu beradaptasi dengan perkembangan zaman. Tidak semua kesenian atau hasil budaya mampu tetap bertahan pada era yang global seperti wayang. Perubahan zaman tidak mungkin bisa dihindari, oleh karena itu, setiap hasil budaya yang tetap bertahan akan selalu memunculkan dinamika-dinamika selaras dengan kebutuhan di masyarakat.

Kata dinamika mengandung nosi kekuatan, selalu bergerak, dan berkembang untuk menyesuaikan diri dengan perubahan kondisi lingungan sekitarnya. Dalam konteks perubahan budaya, maka cara hidup masyarakat yang berkembang dan menyesuaikan diri degan keadaan. Penyesuaian tersebut terjadi karena adanya perubahan-perubahan yang melingkupi kehidupan manusia dalam proses belajar (Yadnya \& Ardika, 2017, p.1). Peru- 
bahan-perubahan yang terjadi di masyarakat mau tidak mau akan selalu terjadi dan akan berdampak pada berbagai aspek kehidupan masyarakat tersebut, tidak terkecuali pada hasil-hasil budayanya.

Dinamika budaya dapat ditemukan dalam dunia pakeliran wayang. Dunia pakeliran wayang sangatlah menarik untuk dibahas, dimana dunia wayang tidak terlepas begitu saja dari dunia kehidupan masyarakat pemiliknya. Wayang bahkan sering disebut sebagai gambaran kehidupan manusia Jawa, karena kata wayang dianggap berasal dari kata bayang, di mana yang dimaksud adalah bayangan manusia (Hazeu melalui Mertosedono, 1994, p.28). Oleh karena itu apa yang ditampilkan di dalam pewayangan sering kali diidentikkan dengan dunia realita atau kehidupan masyarakat. Di dalam praktiknya, cerita-cerita di dalam dunia pakeliran wayang selalu berubah mengikuti perkembangan dunia nyata. Dinamika perubahan yang ada di dalam dunia wayang semakin tampak pada era global seperti sekarang ini. Cerita-cerita yang disampaikan dalam pakeliran bahkan seringkali mengambil sudut pandang dari kehidupan masyarakat saat ini. Hampir seluruh aspek seperti sosial, ekonomi, budaya, politik, bahkan pendidikan sering dibawakan dalam pewayangan.

Salah satu tokoh dalang yang sering membawakan cerita-cerita dengan setting kehidupan masyarakat sekarang ini ialah (alm.) Ki Enthus Susmono. Ki Enthus Susmono merupakan salah satu dalang dengan gaya pesisiran, yaitu gagrak pewayangan yang umumnya dipentaskan di wilayah pesisiran utara Pulau Jawa. Perlu dicatat bahwa wayang pesisiran memiliki corak tersendiri yang menjadi warna pembeda dengan wayang gaya Surakarta dan Yogyakarta. Ki Enthus sebagai dalang membawa warna cerita dan pembawaan gaya yang mencolok sehingga membuatnya sebagai sa- lah satu dalang yang cukup terkenal di nusantara. Ki Enthus dalam membawakan cerita wayang seringkali menggunakan bahasa Indonesia sebagai pengantarnya. Hal tersebut menunjukkan bahwa ada perubahan-perubahan yang coba dibawakan olehnya untuk mengakomodasi pakeliran wayang dalam arus modernisasi.

Penelitian ini bertujuan untuk menyampaikan ciri khas dalam dunia pakeliran wayang gagrag Pesisiran serta dinamika budaya dalam pewayangan ke arah dunia nyata yang termuat di dalamnya. Penelitian mengenai wayang pesisiran maupun dinamika budaya dalam wayang sudah pernah dilakukan sebelumnya. Misalnya saja penelitian yang dilakukan oleh Hariyanto (2018) yang berjudul The Wayang Performance of Enth Susmono: A Resistance of Tegal-Pesisiran Identity in Breaking the Tradition Hegemony. Penelitian tersebut menyampaikan mengenai proses resistensi kultural yang timbul akaibat praktik kekerasan budaya oleh hegemoni pemerintahan di Indonesia. Kekerasan budaya yang dimaksud ialah adanya upaya standardisasi pedalangan yang berpijak pada tradisi Surakarta dan Yogyakarta selama masa orde baru. Resistensi kultural dilakukan oleh Ki Enthus Susmono melalui karya-karya pertunjukkan Wayang Golek Gagrag Tegal untuk mengekspresikan identitas budaya Tegal-Pesisiran.

Penelitian lain yang terkait ialah penelitian yang dilakukan oleh Brata \& Wijayanti (2020) yang berjudul Dinamika Budaya dan Sosial Dalam Peradaban Masyarakat Sunda Dilihat Dari Perspektif Sejarah. Berdasarkan hasil penelitian tersebut ditemukan adanya perkembangan sejarah budaya yang terjadi dalam entitas lokal masyarakat Sunda dan dinamika sosial budayanya. Masyarakat lokal Sunda saat ini juga tengah dihadapkan pada realitas mengenai adanya modernisasi yang 
muncul pada era digital ini. Mengacu pada kedua penelitian tersebut, penelitian yang dilakukan ini memiliki perbedaan yaitu mengkaji tentang perubahan atau dinamika budaya melalui pewayangan Jawa gaya Pesisiran yang mengarah pada dunia realita.

\section{METODE}

Metode penelitian yang digunakan dalam penelitian ini ialah metode penelitian kualitatif, yaitu penelitian yang digunakan untuk membahas serta menguraikan permasalahan yang belum dapat dipahami (Strauss \& Corbin, 1998, p.5). Sumber data yang digunakan ialah video wayang gaya pesisiran dengan lakon Gathutkaca Kelana Jaya oleh Dalang Ki Enthus Susmono sebagai data primer, serta didukung data sekunder berupa hasil wawancara pada dalang pesisiran. Sumber informan ialah salah satu dalang senior wayang pesisiran, $\mathrm{Ki}$ Dhalang Kartono. Informan merupakan berasal dari Lasem yang telah berpengalaman sebagai dalang pesisiran sejak tahun 70-an, serta teman dari Ki Enthus Susmono.

Pengumpulan data dilakukan dengan transkripsi percakapan dalam video wayang dengan teknik simak dan catat, serta wawancara. Analisis data dilakukan dengan analisis kualitatif, yaitu setelah dilakukan pengumpulan data, kemudian dilakukan reduksi data, penyajian data atau kategorisasi, dan pengambilan kesimpulan (Miles \& Huberman, 1992, p.16). Reduksi data dilakukan dengan mereduksi data-data yang tidak sesuai dengan tujuan penelitian. Penyajian data dilakukan dengan memilah data sesuai dengan kategorisasi yang sama untuk dikelompokkan, serta kemudian dilakukan analisis data. Interpretasi dan penarikan kesimpulan didasarkan pada hasil analisis data yang didukung dengan teori-teori dan temuan serta hasil wawancara dari narasumber.

\section{HASIL DAN PEMBAHASAN}

\section{Hasil Penelitian}

Berdasarkan penelitian mengenai wayang pesisiran dapat ditemukan ciri pagelaran wayang pesisiran dan dinamika budaya di dalam pementasannya yang mengarah pada dunia realita. Wayang pesisiran umumnya diawali dengan mengenalkan misi pagelaran sebagai ciri khas dari gaya pesisiran, serta pengenalan karakter atau tokoh utama dalam lakon yang disajikan. Wayang pesisiran juga memiliki ciri khas terkait sajen, gendhing iringan, dan bentuk wayang. Adanya arus modernisasi, menyebabkan dinamika dalam pementasan wayang yang mengarah pada kehidupan nyata, dinamika-dinamika tersebut setidaknya terdiri atas: dinamika religius, dinamika sapaan, dinamika wilayah negara, dinamika sosial budaya, dan dinamika pekerjaan. Adanya perubahan yang terjadi di dalam dunia pementasan wayang tidak luput dari sifat dinamis dan adaptif dari sebuah budaya, dalam hal ini wayang, untuk terus menunjukkan eksistensinya dalam era yang serba global seperti sekarang ini.

\section{Pembahasan}

\section{Ciri Khas Wayang Pesisiran}

Wayang pesisiran dapat dikatakan sebagai jenis wayang yang multigenre (berbagai corak yang tergabung dan terakomodasi dalam satu jenis wayang). Hal tersebut diungkapan narasumber (Ki Kartono) pada saat wawancara. Lebih lanjut, wayang pesisiran mulai berkembang pada tahun 1960-an dan perkembangannya semakin menggejala pada tahun 1970-an pada daerah-daerah pesisir utara $\mathrm{Pu}$ lau Jawa. Perbedaan mencolol wayang gaya pesisiran terletak pada beberapa anasir wayang, misalnya pentas dimulai dengan menyajikan sajen dua jenis, yaitu sajen untuk dalang dan sajen untuk gong (gamelan). Anasir ini 
sangat penting, karena sajen menjadi bagian utama pentas wayang. Berdasarkan keterangan narasumber, pernah terjadi pada saat pementasan, gamelan tidak bisa dimainkan (tidak berbunyi) karena lupa tidak menyajikan sajen untuk gong wayang.

Anasir kedua ialah mengenai iringan wayang gaya pesisiran, dimana iringan gending hanya disiapkan satu jenis, yaitu slendro. Hal tersebut jelas berbeda dengan gaya Surakarta dan Yogyakarta yang menggunakan dua jenis yaitu, slendro dan pelog. Ketiga ialah bentuk wayang yang digunakan, dimana wayang gaya pesisiran menggunakan tambahan wayang golek pada saat awal pementasan. Pemakaian wayang golek ini dilakukan pada saat awal cerita untuk menyampaikan misi pagelaran wayang dan mengenalkan karakter utama wayang dalam lakon yang akan diceritakan. Lebih lanjut, salah satu ciri mencolok yang ditemukan dalam pagelaran wayang yang diusung oleh Ki Enthus Susmono ialah adanya perubahan kode bahasa dalam penyampaian cerita. Hal tersebut tampak pada bahasa Indonesia dalam penyampaian cerita, tidak hanya menggunakan bahasa Jawa saja. Hal tersebut yang membuat ciri khas dari pagelaran wayang gaya pesisiran.

\section{Dinamika Budaya Ke Arah Dunia Realita Wayang Pesisiran \\ Dinamika Religius}

Dinamika religius merupakan sebuah perubahan atau dinamika yang terjadi pada aspek-aspek religiusitas. Sistem religi atau kepercayaan merupakan salah satu dari tujuh unsur kebudayaan yang dikenalkan oleh Koentjaraningrat. Religi atau hal-hal yang berkenaan dengan religiusitas muncul karena adanya pertanyaan mengenai kekuatan gaib atau supranatural yang dianggap lebih tinggi dari manusia. Religi merupakan sebuah kecenderungan rohani yang berhubungan dengan alam semesta ini. Religi memuat tentang keyakinan, upacara dan pirantinya, sikap dan perilaku, alam pikiran dan perasaan di samping hal-hal yang menyangkut para penganutnya (Koentjaraningrat, melalui Firmansyah \& Putrisari, 2017:237).

Dinamika religius yang ditemukan dalam pagelaran wayang kulit pesisiran berkaitan dengan janturan dalam cerita pewayangan. Janturan adalah penggambaran pada jejeran pertama yang meliputi kewibawaan suatu negeri, kerajaan, kehebatan raja, kesaktian, lengkap dengan kondisi dan keadaan seluruh negara yang diiringi dengan gangsa kasirep (bunyi gamelan yang tidak keras), dan disertai wayang di kelir atau layar (Rusdy, 2012, p.67; Nurhayati, 2018, p.106). Janturan pada pagelaran wayang kulit pada saat ini mengalami perubahan, terkait dengan sisi religiusnya. Hal tersebut tampak pada temuan data berikut:

"Bismillah murwani kandha, hambuka wiwaraning carita, hening sesantining $\mathrm{ka}$ la, nir ing rubeda, nir sambekala, purwaning dumadi, ...."

Pada kutipan janturan wayang pesisiran pada lakon Gathutkaca Kelana Jaya tersebut, tampak bahwa janturan diawali dengan kata Bismillah. Kata tersebut mengindikasikan bahwa cerita diawali dengan pujian kepada Tuhan dalam khasazah agama Islam. Hal ini tentu saja telah mengalami perubahan dibandingkan dengan janturan pada pewayangan pada masa lalu. Sebagai pembanding, berikut janturan yang digunakan dalam pewayangan secara konvensional atau sesuai dengan tradisi pakemnya.

\footnotetext{
"Hong Illaheng, hong Illaheng hawignam astu nama sidham, astu silat mring
} 
Hyang Jagadkarana, siran tandha kawisesaning bisana, sana sinawung langen wilapa, ... ." (Rusdy, 2012, p.67)

Berdasarkan kutipan janturan tersebut, dapat diketahui bahwa cerita diawali dengan istilah Hong Illaheng, hong Illaheng hawignam astu nama sidham. Istilah ini merupakan hasil akulturasi religius dari Hindu dan Islam, yaitu pada kata hong dan illaheng. Kata hong, merupakan asonansi dari kata Om (AUM). AUM merupakan penyatuan dari aksara Ang, Ung, dan Mang. Aksara Pranawa Om merupakan aksara suci umat Hindu serta mempunyai nilai magis yang luar biasa sebagai simbol dari Tuhan, Ida Sang Hyang Parama Kawi (Manuaba, 2019, p.11; Paramita, 2020, p.1716). Kata Illaheng berasal dari kata Illahi, yang merujuk Tuhan dalam agama Islam.

Hal tersebut telah menunjukkan bahwa telah terjadi dinamika dalam aspek religiusitas dalam pewayangan saat ini. Adanya perkembangan zaman menyebabkan perubahan dalam penyampaian nilai-nilai yang termuat di dalam pewayangan. Hal ini tentu saja menunjukkan bahwa nilai budaya yang terkandung dalam pewayangan bersifat adaptif dan dinamis terhadap perkembangan peradaban.

\section{Dinamika Sapaan}

Sapaan dalam kehidupan sehari-hari mengalami banyak perubahan. Sapaan bisa menjadi salah satu bukti nyata adanya komunikasi antarmanusia dalam kehidupan bermasyarakat (Wibowo \& Retnaningsih, 2015, p.269). Banyak bentuk sapaan yang digunakan dalam kehidupan sehari-hari masyarakat sebagai bentuk refleksi dari sikap berbahasa masyarakat tersebut. Baik sapaan yang sifatnya nasional sampai pada sapaan yang telah mendapat pengaruh dari sisi religius. Adanya perkembangan zaman yang terjadi di dalam masyarakat berbahasa, maka muncul berbagai bentuk-bentuk sapaan yang digunakan dalam masyarakat tersebut. Dinamika atau perubahan sapaan yang terjadi pada masyarakat berbahasa juga ditemukan dalam dunia pewayangan. Hal tersebut tampak pada kutipan data berikut.

$\begin{array}{ll}\text { Togog } & \text { : “Assalamu'alaikum." } \\ \text { Gareng } & \text { : "Wa'alaikum salam." } \\ \text { Togog } & \text { : "Salam sejahtera." } \\ \text { Gareng } & \text { : "Salam sejahtera." } \\ \text { Togog } & \text { : "Om Swastyastu." } \\ \text { Gareng } & \text { : "Om Swastyastu." }\end{array}$

Berdasarkan pada kutipan tersebut, dapat diketahui bahwa salam yang berupa sapaan di dalam pewayangan tersebut menggunakan sapaan-sapaan yang umum digunakan dalam kehidupan sehari-hari dan bersifat nasional. Salam Assalamu'alaikum merujuk pada salam yang mendapatkan pengaruh dari agama Islam. Salam sejahtera merujuk pada salam yang digunakan oleh umat Nasrani, dan salam Om Swastyastu merupakan salam yang digunakan oleh umat Hindu. Salam-salam sapaan tersebut, saat ini secara umum telah digunakan sebagai salam pembuka dalam budaya nasional di Indonesia dengan tujuan untuk menghormati seluruh hadirin yang hadir.

Bukan tanpa alasan seluruh salam tersebut digunakan, karena Indonesia merupakan negara dengan banyak budaya dan agama, sehingga salam dari berbagai agama jamak digunakan untuk mengakomodasi seluruh kepercayaan yang ada di Indonesia. Hal tersebut merupakan sebuah dinamika yang begitu tampak jika dibandingkan dengan sapaan yang secara konvensional digunakan dalam pewayangan pakem pada zaman dahulu. Pada pakeliran wayang zaman dahulu, sapaan yang digunakan hanya berupa sapaan dengan penanda 
waktu, seperti pagi, siang, sore, ataupun malam.

\section{Dinamika Wilayah Negara}

Dinamika wilayah negara dimaknai sebagai sebuah perubahan yang terjadi dalam dunia pewayangan yang mengarah kepada dunia realita. Artinya, ada perubahan yang tampak dalam penyebutan wilayah kenegaraan yang ada di dalam pewayangan dan dunia realita. Ada perubahan lingkup lintas negara pewayangan dan negara nyata. Wilayah negara merupakan suatu wilayah yang secara konsepsi menjadi kedaulatan negara pemilik wilayah tersebut. Wilayah negara adalah salah satu unsur negara yang merupakan satu kesatuan wilayah darata, perairan, pedalaman, perairan kepulauan dan laut teritorial beserta dasar laut dan tanah di bawahnya, serta ruang udara di atasnya, termasuk seluruh sumber daya kekayaan yang terkandung di dalamnya (UU No. 43 Tahun 2008). Wilayah-wilayah negara yang disebutkan dalam wayang pesisiran tidak lagi sebagai wilayah negara yang secara konvensional digunakan dalam cerita wayang, tetapi sudah menyentuh nama dan wilayah negara dalam kehidupan nyata. Hal tersebut tampak pada data-data dengan ditemukannya nama-nama negara dalam dunia nyata yang disebutkan dalam wayang pesisiran dan menjadi bukti adanya dinamika dalam hal wilayah negara, yaitu: 1) Singapura; 2) Indonesia; 3) Malaysia; 4) China; 5) Thailand; 6) Korea. Salah satu contoh bukti penyebutan negara-negara tersebut sebagai berikut.

Togog: "Kamu katanya kemarin dari Singapore?"

Gareng: "Karena masyarakat ekonomi ASEAN, nanti Indonesia itu akan kedatangan orang-orang ASEAN, dari Thailand, dari mbuak tai (Muangth- ai), dari negara Singapura sing ngecet, Malaysia, terus dari Kroya (Korea)."

Berdasarkan kutipan data tersebut, maka dapat disimpulkan bahwa percakapan yang dilakukan di dalam pewayangan mengenai wilayah-wilayah negara sudah terlepas dari dunia pewayangan. Di mana dalam dunia pewayangan umumnya negara-negara yang disebutkan masih berdasarkan pada pakem cerita seperti negara Astinapura, Amarta, Dwarawati, Ngawangga, Mandura, dan lain sebagainya. Hal tersebut menunjukkan adanya dinamika mengenai wilayah negara dalam cerita yang disajikan dalam lakon tersebut dengan mengarah pada dunia realita. Sebagai pembanding, nama wilayah-wilayah negara yang digunakan dalam pewayangan-pewayangan yang dipentaskan secara tradisional adalah sebagai berikut.

\section{Petruk: "Wah, jagad dewa bathara kowe Sencaki, ... Rakamu Mandura Prabu Baladewa, ... ." \\ Karna: "Rama Prabu keparengan sumene sawetawis ingkang putra wangsul dhateng Ngawangga."}

Selain adanya penyebutan wilayah negara, di dalam cerita tersebut, juga disebutkan nama-nama kota atau daerah yang ada di dalam dunia realita, diantaranya: 1) Jakarta; 2) Tegal; 3) Banjarnegara; 4) Teheran; 5) Solo; 6) Wonogiri; dan 7) Makassar. Hal tersebut tampak pada salah satu kutipan data berikut.

Gareng: "Masyarakat ekonomi ASEAN ini nanti akan berpacu antara kreativitas masyarakat Indonesia dengan masyarakat yang lain. Standar ekonomi ASEAN itu adalah sudah diten- 
tukan, goning Kabupaten Tegal sudah terjadi, melasi temen, Truk."

Berdasarkan kutipan data tersebut, maka dapat disimpulkan bahwa percakapan-percakapan yang terjadi dalam pewayangan sudah menyentuh pada dunia realita, tidak hanya terbatas pada dunia wayang saja. Nama-nama daerah dan kota dalam dunia realita secara jelas disebutkan dalam percakapan. Sebagai pembanding dengan hal tersebut, nama-nama wilayah yang disebutkan dalam pewayangan secara tradisional adalah sebagai berikut.

Kang kinarya sambeting carita, ingkang wonten pakuwon Randhu Gumbala.

Berdasarkan kutipan data tersebut, tampak bahwa nama wilayah yang digunakan dalam pakeliran lama masih menggunakan nama-nama desa atau tempat yang memang menjadi setting cerita dalam lakon tersebut. Dinamika terkait dengan wilayah negara begitu tampak dalam lakon Gathutkaca Kelana Jaya ini, tidak hanya dalam menyebutkan negara saja akan tetapi sampai pada tingkat daerah atau kota dalam dunia realita. Dinamika terkait dengan nama wilayah atau negara pada cerita pewayangan dilakukan dalam upaya mengakomodasi misi pagelaran wayang yang tengah dipentaskan serta sebagai refleksi dari kejadian yang ada di lingkungan masyarakat saat pementasan dilakukan

\section{Dinamika Sosial Budaya}

Dinamika sosial budaya merupakan perubahan yang tidak bisa dihindari oleh setiap masyarakat pemilik budaya. Sifat dinamis budaya akan selalu memaksa adanya perubahan dan perkembangan sesuai dengan kebutuhan zaman yang ada. Semua masyarakat akan mengalami perubahan (Marnelly, 2017, p.149). Perubahan terjadi tentu saja tidak serta merta dalam waktu yang singkat, tetapi dalam waktu yang sangat panjang. Dinamika tersebut juga tampak dalam dunia pewayangan. Dikatakan bahwa suatu negara yang makmur digambarkan sebagai negara yang kuat, hebat, kaya dan sejahtera. Hal tersebut sebagaimana penggambaran suatu wilayah negara di pewayangan pada data berikut.

Hanenggih nagari pundi ingkang kaeka dasa adi purwa. ... . Mila kinarya bebukaning carita. ... . Dhasar Nagari Ngastina kasebut panjang punjung, pasir wukir loh jinawi, gemah ripah kerta raharja.

Dari kutipan data tersebut, disebutkan bahwa negara Astina yang begitu besar digambarkan dengan istilah panjang punjung, pasir wukir loh jinawi, gemah ripah kerta raharja. Artinya, negara Astina sangat terkenal luas, berwibawa luhur, dekat dengan samudra dan memiliki pelabuhan yang besar, memiliki wilayah pegunungan dan mementingkan aspek agraris, murah air, subur, daya beli masyarakat tinggi, banyak dikunjungi orang dari negara lain, dan sebagainya. Hal tersebut menjadi ukuran kebesaran suatu bangsa dan menunjukkan kemakmuran negara pada dunia pewayangan. Akan tetapi di dalam dunia nyata, negara hebat saat ini tidak selalu diidentikkan dengan penggambaran seperti yang telah diuraikan tersebut. Hal itu ditunjukkan dalam kutipan data sebagai berikut.

Gareng: "Bolehlah Singapore hebat, tetapi wc-wc di Singapore tidak ada airnya, adanya tisu. Masa kita kencing pakai tisu? Hahahaha."

Berdasarkan kutipan data tersebut, disebutkan bahwa Singapura merupakan negara 
yang hebat. Hal tersebut tentu saja merupakan suatu fakta yang saat ini dipercayai oleh semua orang. Pada tahun 2004 sebuah lembaga riset, Economic Development Board Singapura, mempublikasikan bahwa Singapura sudah termasuk negara maju dengan pembangunan ekonomi paling kompetitif di dunia (Economic Development Board melalui Tarigan, 2011, p.2). Berdasarkan data publikasi Departement of Statistic Singapore tahun 2006 saja, pendapatan negara Singapura tumbuh sangat signifikan, serta Singapura menjadi tujuan dari ekspor terbesar pelaku bisnis internasional (Tarigan, 2011, p.2). Berdasarkan data tersebut, tidak berlebihan jika mengatakan bahwa Singapura merupakan negara yang hebat. Hal tersebut juga mendorong bukti adanya dinamika bahwa negara yang besar sebagaimana digambarkan dalam dunia pewayangan memiliki perbedaan dengan negara yang ada di dunia nyata. Selain itu, perubahan sosial masyarakatnya juga dapat ditengok dari negara Singapura yang lebih menggunakan tisu daripada air, di mana masyarakat pada negara besar dalam dunia pewayangan lebih dekat dengan aspek agraris yang lebih menggunakan air sebagai sarana yang digunakan dalam hampir seluruh aspek kehidupannya.

\section{Dinamika Pertumbuhan Kehidupan (Kasampurnaning Dumadi)}

Di dalam dunia pewayangan, banyak ditemukan kejadian-kejadian yang terkadang tidak bisa diterima oleh nalar. Hal tersebut tidak mengherankan karena dunia pewayangan seringkali dikaitkan juga dengan dunia spiritual dan mistis. Sebagai contoh, di dalam cerita wayang, tokoh Gathotkaca diceritakan mengalami pertumbuhan yang tidak normal, di mana ia tumbuh dari bayi langsung tiba-tiba menjadi besar. Hal tersebut dikuatkan dari kutipan-kutipan data dalam pewayangan berikut.
Bathara Narada:

“... jabang bayi, putera Bima yang bernama Jabang Tetuka. Maksud dari kami adalah untuk dididik di kawah Candradimuka."

Bathara Narada:

"Satu. Bagaimana caranya Jabang Tetuka bisa menjadi dewasa kemudian menjadi pahlawan, ... ."

Bathara Guru:

“... . Setalah itu, bayi ini akan menjadi sempurna."

Berdasarkan pada kutipan-kutipan data tersebut, dapat disimpulkan bahwasanya tokoh Gathotkaca atau yang bernama Jabang Tetuka itu mencapai tingkat dewasa tidak secara normal sebagaimana pertumbuhan manusia. Saat ia masih bayi kemudian dimasukkan ke dalam kawah Candradimuka bersama dengan unsur-unsur senjata dewata, secara ajaib bisa langsung menjadi dewasa yang sempurna. Secara logis, tentu saja hal ini tidak dimungkinkan, sebagai contohnya saja, kupu-kupu, untuk menjadi bentuk kupu-kupu yang sempurna ia akan mengalami proses metamorfosa yang cukup panjang, yatu dari telur - ulat - kepompong - kupu-kupu. Begitu juga dengn pertumbuhan manusia dalam kehidupan nyata yang memerlukan waktu bertahun-tahun untuk dapat mencapai tingkat kedewasaan yang sempurna.

\section{Dinamika Pekerjaan}

Pekerjaan termasuk dalam salah satu unsur budaya, yaitu mengenai mata pencaharian hidup atau mengarah pada aktivitas ekonomi manusia. Manusia hidup membutuhkan pekerjaan untuk memenuhi segala kebutuhan hidupnya. Pekerjaan pada zaman dahulu di Indonesia, khususnya di Jawa identik dengan sektor agraris yaitu pertanian. Adanya per- 
kembangan zaman menyebabkan saat ini mata pencaharian masyarakat yang berbasis sektor pertanian semakin berkurang, dimana umumnya hanya bisa ditemukan di daerah pedesaan yang relatif belum terpengaruh modernisasi (Nurmansyah, Rodliyah, Hapsari, 2019, pp.79-80). Adanya arus modernisasi dan globalisasi mendorong adanya perubahan mata pencaharian di dalam kehidupan masyarakat.

Di dalam kehidupan modern saat ini pekerjaan merupakan salah satu aspek penting dalam kehidupan. Bahkan tidak sedikit orang yang berlomba-lomba untuk mendapatkan pekerjaan yang dianggap mentereng atau bergengsi untuk dirinya. Pekerjaan yang ada di zaman yang serba global ini juga mengalami banyak perubahan mengikuti dinamika perkembangan zaman. Pekerjaan. Di dalam dunia wayang, umumnya pekerjaan diidentikkan dengan kerajaan, seperti prajurit, senapati perang, peternak, pedagang, dan lain sebagainya. Adanya dinamika terkait dengan pekerjaan di dalam dunia pewayangan saat ini cukup banyak ditemukan pekerjaan-pekerjaan yang tidak lagi bersifat tradisional dalam wayang zaman dahulu. Hal tersebut ditunjukkan dalam kutipan data berikut.

Gareng: "Ha'a. Dia sudah menjadi perwira, Kang."

Gareng: "Ha'a, kalau ini masih bintarabintara lah."

A: "Itu Sekretaris Daerah Wilayah Kahyangan."

Bilung: "Nyong tau dadi TKW, meh ditangkep nang polisi kana koh."

Berdasarkan kutipan data tersebut, dapat diketahui bahwa jenis-jenis pekerjaan yang digunakan atau disebutkan dalam pakeliran wayang pesisiran mengalami banyak perubahan dibandingkan dengan pekerjaan-pekerjaan yang biasa digunakan dalam wayang secara tradisional. Pada data tersebut disebutkan bahwa ada kata perwira dan bintara. Hal tersebut merujuk pada kepangkatan pada Tentara Nasional Indonesia (TNI), berbeda dengan penyebutan kepangkatan prajurit pada wayang yang biasa menggunakan istilah prajurit, wadyabala, atau pangkat yang tertingginya menggunakan kata senapati.

Contoh dinamika pekerjaan yang lainnya ialah adanya penyebutan Sekretaris Daerah Wilayah Kahyangan, yang merujuk pada tokoh Bethara Narada dalam lakon yang dibawakan. Pada pentas wayang tradisional, pekerjaan kepangkatan dalam pemerintaha lebih merujuk pada istilah seperti patih, wadyabala, senapati, atau yang lainnya. Berbeda dengan kepangkatan pemerintahan yang disebutkan yaitu Sekretaris Daerah Wilayah Kahyangan. Pada prosesnya pun, jika dalam kehidupan nyata, Sekda dipilih dengan pemilihan dari partai politik, sedangkan dalam dunia wayang tidak mengenal partai politik, akan tetapi umumnya dengan titah langsung dari raja. Contoh pekerjaan lain yang ada di dunia nyata dan disebutkan dalam pakeliran wayang pesisiran ialah Tenaga Kerja Wanita (TKW). Di dalam dunia wayang tidak mengenal hal tersebut, yang ada ialah masyarakat biasa menjadi mbok emban atau disebut sebagai pengasuh bagi bendara-nya (keluarga raja).

Berdasarkan hasil penelitian dan pembahasan tersebut, maka dapat diketahui bahwa ada banyak sekali aspek-aspek di dalam dunia pewayangan yang mengalami dinamika. Ada perbedaan yang begitu tampak antara wayang gaya Pesisiran dan gaya Yogyakarta dan Solo dari berbagai aspeknya. Di dalam pewayangan gaya Pesisiran cukup banyak aspek-aspek perubahan yang mendekati dunia realita. Artinya di dalam pementasan, dalang menyampaikan hal-hal yang secara langsung bisa ditemukan 
di dunia nyata, tidak lagi hanya dalam anganangan atau cerita fiksi saja. Hal tersebut menjadi dinamika tersendiri dalam pewayangan saat ini, khususnya gaya Pesisiran.

\section{SIMPULAN}

Setiap perubahan waktu yang terjadi memberi dampak perubahan bagi hasil-hasil kebudayaan dan masyarakat pemiliknya. Perubahan dalam kebudayaan tersebut yang dimaksud ialah adanya dinamisasi yang terjadi pada hasil budaya tersebut untuk menyesuaikan diri dengan kebutuhan sesuai dengan zaman di mana kebudayaan tersebut ada. Hal tersebut tidak terkecuali juga terjadi pada dunia pewayangan, di mana hal tersebut menjadi salah satu bukti eksistensi wayang sejak jaman dahulu hingga pada zaman yang serba modern saat ini. Di dalam pakeliran wayang saat ini, terjadi banyak dinamika yang termuat dalam pertunjukkannya. Penelitian terkait dengan dinamika dalam budaya pewayangan ke arah dunia realita ini memberikan gambaran bahwa saat ini perkembangan pementasan wayang sudah begitu dekat dengan kehidupan masyarakat.

Salah satu wujud dinamika pada pementasan wayang tampak pada pakeliran wayang pesisiran. Wayang pesisiran memiliki ciri khas yang membedakan dengan gaya pewayangan seperti gaya Yogyakarta dan Surakarta. Ciri khas yang dimiliki oleh wayang pesisiran menjadi salah satu bentuk adanya dinamisasi dalam dunia pekeliran. Wayang pesisiran yang dipertunjukkan juga menyiratkan adanya banyak dinamika yang terakomodasi dalam pertunjukkannya. Dinamika yang terjadi dalam wayang pesisiran antara lain terkait dengan religius, sapaan, wilayah negara, sosial budaya, pertumbuhan kehidupan atau kasampurnaning dumadi dan pekerjaan. Dinamika yang ada pada wayang pesisiran menggambarkan adanya perubahan yang terjadi dari dunia pewayangan ke arah dunia realita. Hal ini menjadi indikasi bahwa akan semakin banyak perkembangan atau dinamika yang terdapat dalam pewayangan sebagai bagian adaptasi budaya pewayangan terhadap perkembangan dunia. Penelitian terkait dengan dinamika-dinamika dalam budaya pewayangan perlu dilanjutkan untuk mengetahui beragam adaptasi dan perkembangan dalam budaya pewayangan tersebut.

\section{DAFTAR PUSTAKA}

Basir, U.P.M. Konstelasi Bahasa Jawa Modern dalam Pagelaran Wayang Kulit Purwa (Kajian Sosiolinguistik). Jurnal Diksi, 16(1), 42-54. https://doi.org/10.21831/ diksi.v16i1.6567

Brata, Y.R., Wijayanti, Y. (2020). Dinamika Budaya dan Sosial Dalam Peradaban Masyarakat Sunda Dilihat Dari Perspektif Sejarah. Jurnal Artefak, 7(1), 1-12. http://dx.doi.org/10.25157/ja.v7i1.3380

Firmansyah, E.K. \& Putrisari, N.D. (2017). Sistem Religi dan Kepercayaan Masyarakat Kampung Adat Kuta Kecamatan Tambaksari Kabupaten Ciamis. Jurnal Pengabdian Masyarakat, 1(4), 236-243. http://jurnal.unpad.ac.id/pkm/article/ view/16403/7984

Hariyanto. (2018). The Wayang Performance of Enthus Susmono: A Resistance of Tegal-Pesisiran Indentity in Breaking the Tradition Hegemony. Jurnal Tari, Teater, dan Wayang, 1(1), 1-12. https://doi. org/10.24821/dtr.v1i1.2246

Koentjaraningrat. (2003). Pengantar Antropologi. Jakarta: Aksara Baru.

Manuaba, I.G.S.Y. (2019). Aksara Bali dalam Upacara Dwijati Di Gruya Agung Bangkasa, Desa Bongkasa, Kecamatan Abiansemal, Kabupaten Badung. Jurnal Pang- 
kaja, 22(2), 9-22. http://www.ejournal. ihdn.ac.id/index.php/PJAH/article/ view/1684/1327

Ma'ruf, A., Komariah, S., Wildan, D. (2020). Pertunjukkan Wayang sebagai Rekonstruksi Nilai Tuntunan dan Tontonan dalam Pembelajaran Sosiologi. Sosietas Jurnal Pendidikan Sosiologi, 10(1), 754764. https://doi.org/10.17509/sosietas. v10i1.26000

Marnelly, T.R. (2017). Dinamika Sosial Budaya Masyarakat Melayu Pesisir (Studi Pengelolaan Madu Sialang di Desa Rawa Mekar Jaya). Jurnal Antropologi: Isu-isu Sosial Budaya, 19(2), 149-154. https:// doi.org/10.25077/jaisb.v19.n2.p149154.2017

Mertosedono, A. (1994). Sejarah Wayang, Asal-usul, Jenis dan Cirinya. Semarang: Dahara Prize.

Miles \& Huberman. (1992). Analisis Data Kualitatif. Jakarta: Universitas Indonesia Press.

Normina. (2017). Pendidikan dalam Kebudayaan. Ittihad Jurnal Kopertais Wilayah XI Kalimantan, 15(28), 17-28. https://10.18592/ittihad.v15i28.1930

Nurdiyanto, W. (2017, November 7). Peristiwa Penting 7 November, Wayang Ditetapkan Sebagai Warisan Budaya Dunia. Times Indonesia. https://www.timesindonesia.co.id/read/news/160562/ peristiwa-penting-7-november-wayangditetapkan-sebagai-warisan-budaya-dunia

Nurhayati, E. (2008). Sistem Sapaan dalam Wayang Kulit. Jurnal Diksi, 15(2), 137148. https://doi.org/10.21831/diksi. v15i2.6602

Nurhayati, E. (2018). Sosiolinguistik: Kajian Kode Tutur dalam Wayang Kulit. Yogyakarta: Kanwa Publisher.
Nurmansyah, G., Rodliyah, N., \& Hapsari, R.A. (2019). Pengantar Antropologi: Sebuah Ikhtisar Mengenal Antropologi. Bandang Lampung: Aura Publisher.

Paramita, E.P. (2020). Simbolisasi benang tri datu sebagai komunikasi kultural umat hindu berdasar telaah teori komunikasi. Widya Sandhi, 9(2), 1705-1718. http://e-journal.stahn-gdepudja.ac.id/index.php/WS/article/view/100

Rahyono, F.X. (2009). Kearifan Budaya dalam Kata. Jakarta: Wedatama Widya Sastra.

Rusdy, S.T. (2012). Ruwatan Sukerta \& Ki Timbul Hadiprayitno. Yogyakarta: Yayasan Kertagama.

Strauss, A. \& Corbin, J. (1998). Basic of Qualitative Research: Techniques and Procedures for Developing Grounded Theory $\left(2^{\text {nd }}\right.$ ed.). California: Sage Publications Inc.

Tarigan, P. (2011). Faktor Pendukung Keberhasilan Singapura sebagai Salah Satu Pusat Perdagangan Dunia (Kajian Perspektif Multinational Corporation di Singapura). Jurnal Ekonomi, 13(1), 1-55. https://doi.org/10.37721/je.v13i1.60

Undang-Undang Republik Indonesia Nomor 43 Tahun 2008 Tentang Wilayah Negara.

Wibowo, R.M., Retnaningsih, A. (2015). Dinamika Bentuk-bentuk Sapaan Sebagai Refleksi Sikap Berbahasa Masyarakat Indonesia. Jurnal Humaniora, 27(3), 269282. https://doi.org/10.22146/jh.10587

Widyosiswoyo, S. (1992). Ilmu Budaya Dasar. Bogor: Ghalia Indonesia.

Yadnya, I.B.P \& Ardika, I.W. (Ed.). (2017). Dinamika Manusia Dan Kebudayaan Indonesia Dari Masa Ke Masa. Denpasar: Pustaka Larasan. 